\title{
PROXIMATE COMPOSITION AND FUNCTIONAL PROPERTIES OF COMPOSITE SORGHUM-OKARA FLOUR AND SENSORY EVALUATION OF LOCAL SNACK PRODUCT (SOSA).
}

\author{
*Uzo-Peters, P.I. and Ola S.T.
}

Department of Food Technology, University of Ibadan, Ibadan, Nigeria

*Corresponding Author: zophyl@yahoo.com; olasammie257@gmail.com

\begin{abstract}
Partial substitution of cereals with legumes has the potential to improve the nutritional content, functionality and other properties of the composite flour. This study aimed at ascertaining the effect of partially substituting sorghum flour with okara flour and also to access the acceptability of a snack product, sosa, produced from the flour blends. The blends were produced from sorghum and okara flour using the following proportions respectively; 100:0; 90:10; 80:20; 70:30; and 60:40 with 100\% sorghum serving as control. Results of the proximate composition of the flour blends showed an increase in protein (8.18\%-22.73\%), fat (1.7\%-5.53\%), crude fiber (2.9\%-11.55\%) and ash (1.72\%$2.83 \%)$, while the carbohydrate content decreased from $(73.21 \%$ to $46.55 \%)$, with the moisture content varying between $(10.81 \%$ and $12.41 \%)$. Bulk densities decreased with increase in okara substitution from $1 \mathrm{~g} / \mathrm{ml}$ to $0.72 \mathrm{~g} / \mathrm{ml}$. The water absorption capacity and oil absorption capacity increased with increase in okara substitution from $278.67 \mathrm{ml} / 100 \mathrm{~g}$ to $328 \mathrm{ml} / 100 \mathrm{~g}$ and $177.33 \mathrm{ml} / 100 \mathrm{~g}$ to $249.33 \mathrm{ml} / 100 \mathrm{~g}$ respectively. The flour blends produced can all serve as thickeners and the local snack (sosa) produced from the flour blends was favourably accepted by the panelists.
\end{abstract}

Keywords: Local snacks: supplementation: sorghum-okara: composite flour. 


\section{INTRODUCTION}

Soya bean pulp (okara) is the solid left over from the processing of soymilk (Porcel et al., 2017b). As a result of it being a by-product, there has been a neglect of its nutritional value and potential uses (Aguado, 2010). Nevertheless, with the prevailing high levels of malnutrition in sub-Saharan. Africa, it has a high potential of becoming an important food source. Okara can be dried and processed to flour which can be incorporated in making several food products. Sorghum (Sorghum bicolor L. Moench), is the fifth most significant grain after wheat, maize, rice and barley (Taylor, 2003). It is gluten free and can be digested by celiac patients. This makes it an appropriate substitute for gluten cereals such as wheat, thus creating opportunities for products made using sorghum flour to thrive commercially (Winger et al., 2014). However, there is a need to complement cereal grains with legumes in order to improve their nutritional availability (Balogun et al., 2012). Over the years, snacking has been linked to poor food intake because of their lack of basic nutrients and the prevailing high levels of calories, salt, fat and sugar they mostly contain (Kolawole et al., 2013). Conversely, in such a busy world as ours today desperately in need of convenience food items that requires little effort and times to prepare, researches on nutritious and healthy snack products are gaining more prominence and attention than ever before (Hess et al., 2016). Due to okara being rich in dietary fiber and nutrients, it has been utilized by researchers in making various food products such as; bread (Wickramarathna and Arampath, 2003) and (Porcel et al., 2017a), okara/rice cake (Xie et al., 2008), biscuits and muffins (Aguado, 2010), cookies (Porcel et al., 2017b) and so on. It has also been utilized as part of formulations for developing gluten free flour (Aguado, 2010 and Porcel et al., 2017b) which is suitable for celiac disease patients. The aim of this study was to verify the effect of partial replacement of sorghum flour with okara flour on selected properties and to assess the acceptability of a snack (sosa) produced from the composite flour blends.

\section{MATERIALS AND METHODS Source of Materials}

All ingredients were procured from Bodija market in Ibadan, Oyo state, Nigeria. All reagents used in the analysis were of analytical grade. The experiment was carried out in the Food Processing and Food Chemistry Laboratory, Department of Food Science, University of Ibadan, Ibadan, Oyo State, Nigeria. 


\section{Production of Sorghum-okara Flour Samples}

Cleaned Sorghum grains were dry milled using a milling machine, sieved with a sieve of $200 \mu \mathrm{m}$ mesh size then stored for use in seal lock cellophane bags at room temperature $\left(28 \pm 2^{\circ} \mathrm{C}\right)$. Soya bean seeds soaked overnight were ground in a blender then sieved using a muslin bag. The resultant cake was dried in an air oven at $50^{\circ} \mathrm{C}$ for 8 hours, ground and sieved using a sieve of mesh size $200 \mu \mathrm{m}$ and stored for use in seal lock cellophane bags at room temperature $\left(28 \pm 2^{\circ} \mathrm{C}\right)$. Composite flours of the sorghum flour and okara flour were then formulated using varying proportions of Okara flour at ratios; 100:0, 90:10, 80:20, 70:30 and $60: 40$ respectively. The $100 \%$ sorghum sample served as the control.

\section{Production of Sosa.}

The formulation was made up of sorghum-okara composite flour $(39.1 \%)$, banana $(37 \%)$, margarine $(9.2 \%)$, egg $(8.2 \%)$, sugar $(6.1 \%)$, baking powder $(0.26 \%)$, nutmeg $(0.08 \%)$ and salt $(0.06 \%)$. Firstly, the oven was preheated to $180^{\circ} \mathrm{C}$ while the butter and sugar were mixed together until light and fluffy. The eggs were beaten separately until foam was formed, then added to the mixture of the butter and sugar. The mixture was stirred continuously until a light and fluffy consistency was attained. The bananas were then mashed and mixed with the baking powder using a mixer which was allowed to sit for 2 minutes, then mixed into the butter mixture. In another separate bowl, the dry ingredients (flour, salt and nutmeg) were mixed together. This was added to the bananabutter mixture to form the dough. The dough was dropped in dollops onto a greased tray and baked for 12 minutes until a golden brown colour was developed. The snacks were cooled and packaged in an air tight container. The flow chart illustrating the process is shown in figure 1 below. 


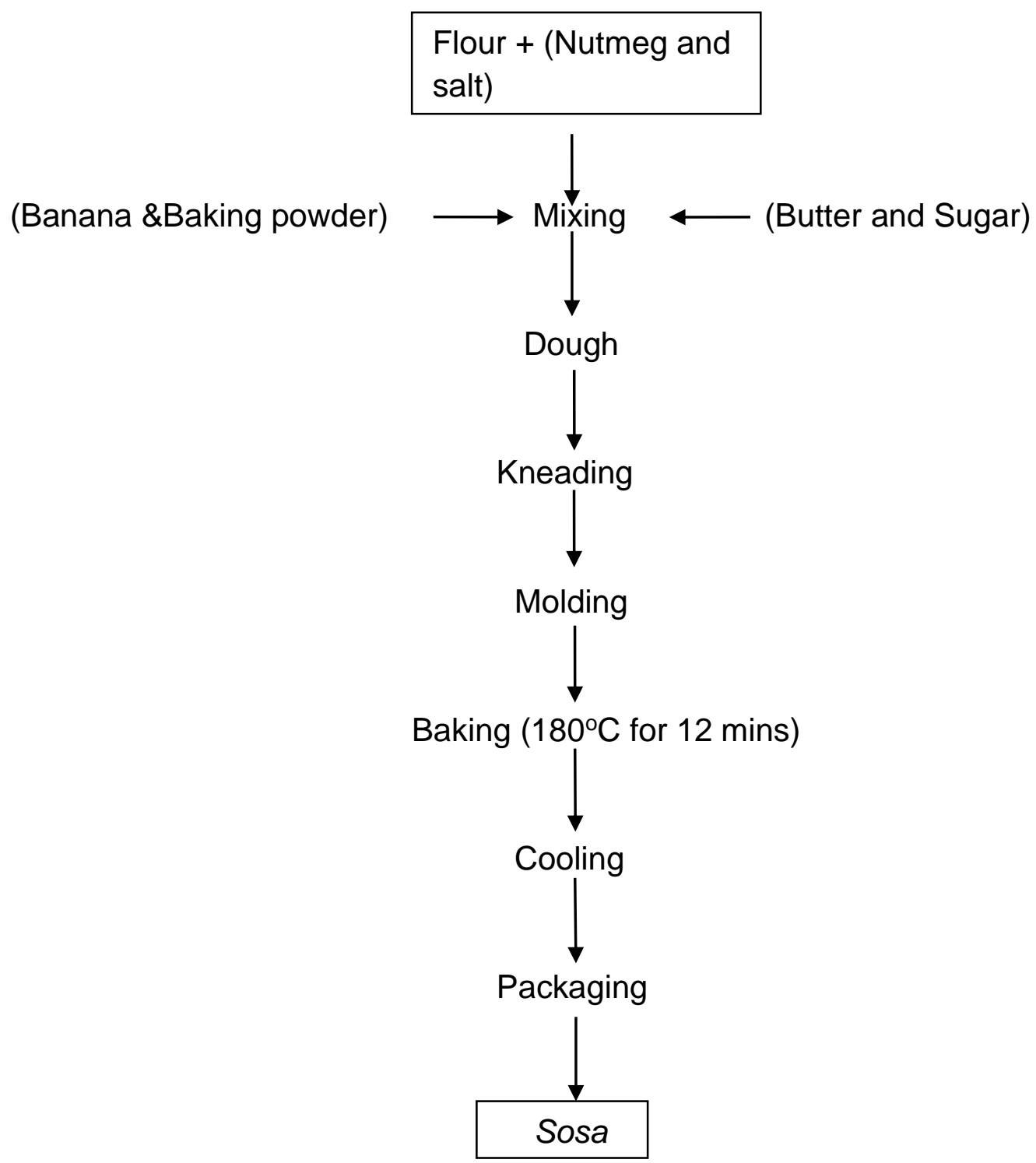

Figure 1: Production of Sosa.

(Adapted from simplyrecipes.com)

\section{Analysis of the Proximate Composition of the Flour Blends}

The Association of Official Analytical Chemist (A.O.A.C, 2005) standard procedure was used to determine the proximate composition of the SorghumOkara flour blends. The moisture content was determined by oven drying (AOAC - 925.10), fat by soxhlet extraction (AOAC - 2003.05), ash by combustion (AOAC - 923.03) and protein (AOAC - 960.52) content $(\mathrm{N} \times 6.25)$ by micro Kjeldahl method. 


\section{Functional Properties of Sorghum-Okara Flour Samples Determination of Bulk Density}

The bulk density of each of the flour samples was determined according to the method of Onwuka (2005). A sample $(1 \mathrm{~g})$ was measured into a cylinder and tapped continually until there was no noticeable change in volume. The volumes before and after tapping the cylinder were taken note of and the difference in the bulk density was recorded in $\mathrm{g} / \mathrm{ml}$ as;

\section{Bulk Density $=\quad$ Weight of sample $(g)$ \\ Volume of sample before tapping $(\mathrm{ml})$-Volume after tapping $(\mathrm{ml})$}

\section{Determination of Water and Oil Absorption Capacities.}

Water absorption capacity was determined using the method described by Falade and Okafor (2015). Sample of $(1 \mathrm{~g})$ was weighed into a calibrated $25 \mathrm{ml}$ conical centrifuge tube. The weight of centrifuge tube and content was taken and recorded. $10 \mathrm{ml}$ of distilled water and $10 \mathrm{ml}$ of groundnut oil were added into centrifuge tubes for both water absorption and oil absorption capacities respectively. The mixtures were made to stand at room temperature $\left(28 \pm 2^{\circ} \mathrm{C}\right)$ for 30 minutes. Centrifugation at 400rpm for 20 minutes on an Eppendorf Centrifuge (Model No. 5810R, Gaithersburg, USA) followed subsequently. The liquid was separated from the sediment after centrifugation and then the sample was reweighed. The water absorption capacity and oil absorption capacity were recorded in $\mathrm{g} / \mathrm{g}$ as;

WAC/OAC = Weight of tube after centrifugation $(g)$ - initial weight of tube (g)

\section{Weight of sample $(g)$}

\section{Sensory Evaluation}

Sensory evaluation of the snacks produced was conducted using 25 panelists selected at random from the Department of Food Technology, University of Ibadan. The samples were represented with codes and accessed using the nine-point hedonic scale for taste, colour, mouth feel, aroma and overall acceptability. 


\section{Statistical Analysis of Data}

Data obtained from all analyses were subjected to Statistical Analysis of Variance (ANOVA) using SPSS version 20. Means were separated using Duncan's Multiple Range Test (DMRT).

\section{RESULTS AND DISCUSSION}

Values of the proximate composition are shown in Table1. The protein content of the samples was significantly higher than that of the control (100:0). An increase in protein content was observed with an increase in the level of okara substitution. The control sample recorded a value of $8.18 \%$ while the highest replacement level of $40 \%(60: 40)$ had a value of $22.73 \%$. This increase is expected since Okara has a high protein content as a result of it being processed from soybeans which is a known rich source of protein and the essential amino acid, lysine. (Babayeju et al., 2017) This increase in protein content will serve to complement the amino acid profile of sorghum which is limiting in lysine (Vaclavik and Christian, 2008). There was a significant increase in the fat and fiber contents with increase in okara substitution. The increase in the fat content can also be linked to the source of okara; soybeans which is very rich in oil, containing about $20 \%$ (Osho and Taylor, 2005). The increase in fiber content proves that okara is rich in fiber, a major reason why it has been utilized by various researchers in making food products (Aguado, 2010 and Porcel et al., 2017a). The results of the functional properties are presented in Table 2 . The bulk density decreased significantly with increase in okara content from $1.00 \mathrm{~g} / \mathrm{ml}(100: 0)$ to $0.72 \mathrm{~g} / \mathrm{ml}(60: 40)$. Bulk density is a measure of heaviness of solid samples, which is important for determining packaging requirements, material handling and application in the food industry (Falade and Okafor, 2015). According to Akubor and Badifu (2004), flours with high bulk densities $(>0.7 \mathrm{~g} / \mathrm{ml})$ can be used as thickeners in food products. Hence, the flours in this study could be suitable as thickeners. Water absorption capacity refers to the amount of water retained by a food product after filtration and application of mild pressure of centrifugation (Falade and Okafor, 2015). This is an important factor in processing of soups, doughs, custards, sausages, where it is important to imbibe water without dissolution of protein, thus attaining perfect thickening and optimum viscosity (Otegbayo et al., 2013). The values for water absorption increased significantly with increase in okara substitution from $278.67 \mathrm{ml} / 100 \mathrm{~g}(100: 0)$ to $328 \mathrm{ml} / 100 \mathrm{~g}(60: 40)$, though a deviation in trend occurred at 70:30 $(283.67 \mathrm{ml} / 100 \mathrm{~g})$. The noted increase in water absorption with increase in okara could be attributed to the fact that it 
increases with increase in protein content (Agaudo, 2010 and Otegbayo et al., 2013). Oil absorption capacity refers to protein's ability to bind fat. It is an important factor since fats acts as flavor retainers and increases the mouth feel of foods (Otegbayo et al., 2013). Generally, oil absorption capacity increases with increase in fat content due to increased lipid interactions. This was also observed in the results of the flours with the values increasing significantly with increase in okara substitution from $177.33 \mathrm{ml} / 100 \mathrm{~g}(100: 0)$ to $249.33 \mathrm{ml} / 100 \mathrm{~g}$ (60:40). The results of the quality attributes are presented in Table 3 . The results showed that the product made from 70:30 sorghum to okara blend was the least preferred for all parameters accessed (except aroma) and was significantly different from all others. In terms of taste, there was notable difference in the values for 100:0,90:10 and 60:40. Generally, all the product samples were accepted by the panelists for all parameters accessed.

Table 1: Proximate analysis of the flour blends

\begin{tabular}{lllllll}
\hline $\begin{array}{l}\text { Sorghum } \\
\text { Okara }\end{array}$ & Protein(\%) & Fat (\%) & Fiber (\%) & Ash (\%) & $\begin{array}{l}\text { Moisture } \\
(\%)\end{array}$ & $\begin{array}{l}\text { Carbohydrate } \\
(\%)\end{array}$ \\
\hline$(\%)$ & & & & & & \\
$100: 0$ & $8.18 \pm 1.06^{\mathrm{e}}$ & $1.7 \pm 0.2^{\mathrm{d}}$ & $2.9 \pm 0.15^{\mathrm{e}}$ & $1.72 \pm 0.21^{\mathrm{c}}$ & $12.29 \pm 0.13^{\mathrm{a}}$ & $73.21 \pm 1.75^{\mathrm{a}}$ \\
& & & & & & \\
$90: 10$ & $11.58 \pm 0.15^{\mathrm{d}}$ & $3.6 \pm 0.13^{\mathrm{c}}$ & $3.72 \pm 0.14^{\mathrm{d}}$ & $2.1 \pm 0.25^{\mathrm{b}}$ & $12.41 \pm 0.82^{\mathrm{a}}$ & $66.59 \pm 0.75^{\mathrm{b}}$ \\
$80: 20$ & $15.1 \pm 1.48^{\mathrm{c}}$ & $4.09 \pm 0.36^{\mathrm{b}}$ & $5.5 \pm 0.41^{\mathrm{c}}$ & $2.21 \pm 0.14^{\mathrm{b}}$ & $12.13 \pm 0.33^{\mathrm{a}}$ & $60.97 \pm 2.7^{\mathrm{c}}$ \\
$70: 30$ & $17.6 \pm 0.69^{\mathrm{b}}$ & $5.15 \pm 0.16^{\mathrm{a}}$ & $8.1 \pm 0.32^{\mathrm{b}}$ & $2.34 \pm 0.21^{\mathrm{b}}$ & $12.12 \pm 0.22^{\mathrm{a}}$ & $54.69 \pm 1.6^{\mathrm{d}}$ \\
& & & & & & \\
$60: 40$ & $22.73 \pm 1.2^{\mathrm{a}}$ & $5.53 \pm 0.33^{\mathrm{a}}$ & $11.55 \pm 0.34^{\mathrm{a}}$ & $2.83 \pm 0.27^{\mathrm{a}}$ & $10.81 \pm 0.23^{\mathrm{b}}$ & $46.55 \pm 2.33^{\mathrm{e}}$
\end{tabular}

Means with the same superscripts within the same column are not significantly different $(P>0.05)$. Values are mean of triplicate determinations. $a>b>c>d>e$. 
Table 2: Functional properties of the flour blends

\begin{tabular}{|c|c|c|c|c|c|c|}
\hline $\begin{array}{l}\text { Sorghum: } \\
\text { Okara } \\
(\%)\end{array}$ & \multirow[t]{2}{*}{$\begin{array}{l}\text { Bulk density } \\
(\mathrm{g} / \mathrm{ml})\end{array}$} & \multicolumn{2}{|c|}{$\begin{array}{l}\text { Water } \\
\text { Absorption } \\
\text { Capacity }\end{array}$} & \multicolumn{2}{|c|}{$\begin{array}{l}\text { Oil Absorption } \\
\text { Capacity } \\
\text { (ml/100g) }\end{array}$} & \\
\hline & & \multicolumn{2}{|c|}{$(\mathrm{ml} / 100 \mathrm{~g})$} & \multirow{2}{*}{\multicolumn{2}{|c|}{$177.33 \pm 1.15^{d}$}} & \\
\hline 100:0 & $1.00 \pm 0.03^{a}$ & \multicolumn{2}{|c|}{$278.67 \pm 0.57^{e}$} & & & \\
\hline $90: 10$ & $0.84 \pm 0.02^{b}$ & \multicolumn{2}{|c|}{$293.33 \pm 2.30^{c}$} & \multicolumn{2}{|c|}{$207.33 \pm 1.52^{c}$} & \\
\hline $80: 20$ & $0.77 \pm 0.02^{c}$ & \multicolumn{2}{|c|}{$309.33 \pm 2.08^{b}$} & \multicolumn{2}{|c|}{$207.67 \pm 1.15^{c}$} & \\
\hline $70: 30$ & $0.75 \pm 0.17^{\mathrm{cd}}$ & \multicolumn{2}{|c|}{$283.67 \pm 2.08^{d}$} & \multicolumn{2}{|c|}{$238.00 \pm 2.00^{b}$} & \\
\hline $60: 40$ & $0.72 \pm 0.02^{d}$ & \multicolumn{2}{|c|}{$328.00 \pm 4.00^{a}$} & \multicolumn{2}{|c|}{$249.33 \pm 4.51^{a}$} & \\
\hline \multicolumn{7}{|c|}{$\begin{array}{l}\text { Means with the same superscripts within the same column are not significantly } \\
\text { different }(P>0.05) \text {. Values are means of triplicate determinations. } a>b>c>d>e \text {. }\end{array}$} \\
\hline $\begin{array}{l}\text { Samples } \\
\text { Sorghum: } \\
\text { Okara }\end{array}$ & Taste & Colour & Mout & & Aroma & $\begin{array}{l}\text { Overall } \\
\text { Acceptability }\end{array}$ \\
\hline $100: 0$ & $7.64 \pm 1.22^{\mathrm{a}}$ & $6.80 \pm 1.11^{\mathrm{a}}$ & 7.20 & & $6.80 \pm 1.29^{a}$ & $7.40 \pm 1.11^{\mathrm{a}}$ \\
\hline $90: 10$ & $7.20 \pm 1.50^{\mathrm{a}}$ & $6.56 \pm 1.53^{\mathrm{ab}}$ & 6.68 & $4^{\mathrm{ab}}$ & $6.96 \pm 1.30^{\mathrm{a}}$ & $7.20 \pm 1.08^{\mathrm{a}}$ \\
\hline 80:20 & $7.00 \pm 1.32^{\mathrm{ab}}$ & $6.60 \pm 1.08^{\mathrm{ab}}$ & 6.92 & & $6.64 \pm 1.28^{a}$ & $6.68 \pm 0.90^{a b}$ \\
\hline 70:30 & $6.24 \pm 2.18^{\mathrm{b}}$ & $6.00 \pm 1.04^{b}$ & 5.88 & & $6.60 \pm 1.58^{a}$ & $6.08 \pm 1.38^{b}$ \\
\hline $60: 40$ & $7.28 \pm 1.40^{a}$ & $6.60 \pm 1.19 \mathrm{ab}$ & 6.68 & $10^{\mathrm{ab}}$ & $6.84 \pm 1.31^{a}$ & $6.96 \pm 1.59^{a}$ \\
\hline
\end{tabular}

Means with the same superscripts within the same column are not significantly different $(P>0.05) . a>b$.

\section{CONCLUSION AND RECOMMENDATIONS}

Composite flour can be derived from sorghum and okara which is suitable for individuals sensitive to gluten. In addition, the flours produced from this study can be used as thickeners due to the high bulk density values recorded. The snack product produced during the study was accepted by the panelists. However, it is recommended that further research work should be carried to determine the proximate analysis of the snack product and other properties of 
the composite flour such as pasting properties, mineral composition, bioavailability and microbial analysis. Also, various ways of utilizing the flour product should be sought out and implemented.

\section{REFERENCES}

Aguado, A. (2010). Development of Okara powder as a gluten free alternative to all purpose flour for value added use in baked goods. Unpublished Ph.D thesis. Faculty of the Graduate School of the University of Maryland, College Park, Md, USA.

Akubor, P.I. and Badifu, G.I. (2004). Chemical composition, functional properties and baking potential of African breadfruit kernel and wheat flour blends. International Journal of Food Science and Technology, 39(2),223-229.

Association of Official Analytical Chemists (AOAC) (2005).Official method of analysis. $18^{\text {th }}$ Edition, Association of Official Analytical Chemists, Washington DC.

Babayeju, A.A., Nmom, I.O., Obalowu, M.A., Adebisi, T.T and Gbadebo, C.T. (2017). Sensory attributes and consumption of melon-soybean soup blends with Indian spinach vegetables in Ilorin, Kwara state, Nigeria. Agrosearch, 17(1),89-100.

Balogun M.A., Karim O.R., Kolawole, F.L. and Solarin A.O. (2012). Quality Attributes of Tapioca Meal Fortified with Defatted Soy Flour. Agrosearch,12(1), $61-68$.

Falade, K.O. andOkafor, C.A. (2015). Physical, functional and pasting properties of flours from corms of two cocoyam (Colocasta esculenta and Xanthosoma sagitti folium) cultivars. Journal of Food Science and Technology,52(6), 3440-3448.

Hess, J.M.Jonnalagadda, S.Sand Slavin, J.L. (2016). What is a snack, Why do we snack, and how can we choose better snacks? A review of the definitions of snacking, motivations to snack, contributions to dietary intake and recommendations for improvement. Advances in Nutrition, 7(4),466475.

Kolawole, F.L., Balogun, M. A., Opaleke, D.O. and Amali, H.E.(2013). An Evaluation of Nutritional and Sensory Qualities of Wheat Moringa Cake. Agrosearch,13(1), 87 - 94.

Onwuka G. I. (2005). Functional properties in: Food analysis and instrumentation. Pp 134-135 Naphtali Prints, Lagos. 
Osho, S.M and Taylor, O.A (2005). The Production of a Low Dietary Bulk Density Cassava-based Weaning Food Using Fermentation. Agrosearch,7(1), 5-11.

Otegbayo, B.O.Samuel, F.O and Alalade, T. (2013). Functional properties of soy-enriched tapioca. African Journal of Biotechnology, 12(22),35833589.

Porcel, M.V.O., Campderros, M.E., and Rinaldoni, A.N. (2017). Effect of Okara flour addition on the physical and sensory quality of wheat bread. MOJ Food Processing and Technology, 4(6), 184-190.

Porcel, M.V.O., Quiroga-Panelo, N., Rinaldoni, A.N., and Campderros M.E. (2017). Incorporation of Okara into Gluten-Free Cookies with High Quality and Nutritional Value. Journal of Food Quality, 4071585, 1-8.

Taylor, J.R.N. (2003). Overview: Importance of Sorghum in Africa.Proceedings of AFRIPRO workshop on the proteins of sorghum and millets: Enhancing nutritional and functional properties for Africa.

Wickramarathna, G.L. and Arampath, P.C. (2003). Utilization of Okara in Bread making. Journal of Bioscience, 31,29-33.

Winger, M. Khouryien, H. Aramouni, F. and Herald, T. (2014). Sorghum Flour Characterization and Evaluation in Gluten free Flour Tortilla. Journal of Food Quality, 37(2), 95-106.

www.simplyrecipes.com. Banana Cookies Recipe. Accessed on January 25, 2019.

Vaclavik, V.A and Christian, E.W. (2008). Essentials of Food Science. $3^{\text {rd }}$ Edition. New York. Springer.

Xie, M., Hugg, H., Hsieh, F., and Mustapha, A. (2008). Puffing of okara/rice blends using a rice cake machine. Journal of Food Science, 73(8), E341E348. 